"Todas as falhas e virtudes desse povo": considerações sobre a composição racial da Força Expedicionária Brasileira $^{1}$

"All the failures and virtues of this people": considerations about the racial composition of the Brazilian Expeditionary Force

Francisco Cesar Alves Ferraz ${ }^{2}$ 
Resumo: Entre 1944 e 1945, o Brasil enviou um pequeno exército de 25 mil homens, a Força Expedicionária Brasileira (FEB), para combater as forças do Eixo na Segunda Guerra Mundial. Essa força foi caracterizada por ser a única combatente, em toda a guerra, que foi integrada, em termos raciais. Tão importante quanto a integração, a composição da FEB foi retratada, na época e na memória coletiva, como uma “amostra racial” do Brasil. Essa imagem de relações raciais harmônicas também ajudou a alimentar o mito da democracia racial. O objetivo deste artigo é revisar a formação racial da FEB, verificando a documentação disponível em arquivos militares e civis brasileiros e a historiografia recente. Este estudo conclui que a FEB, com ligeiras diferenças, reproduziu a estrutura racial da população brasileira em sua composição. No entanto, esse "caldeirão multiétnico e cultural” foi uma consequência não planejada do processo de recrutamento da divisão expedicionária, uma vez que o objetivo das autoridades do Exército era recrutar uma "elite”, com critérios de saúde física e alfabetização que poderiam ser excludentes para uma parte da juventude não branca. No entanto, devido às dificuldades de recrutamento seletivo e evasão de parte das classes média e alta, predominantemente brancas, foi enviado para a guerra uma tropa com origens raciais e culturais que pode ser considerada uma espécie de “amostra” da sociedade brasileira.

Palavras-chave: Força Expedicionária Brasileira; Exército Brasileiro; Relações raciais; Democracia racial.

Abstract: Between 1944 and 1945, Brazil sent a small army of 25,000 men to fight the Axis forces in World War II, the Brazilian Expeditionary Force (FEB). This force was characterized by being the only fighting force in the entire war that was racially integrated. As important as integration, FEB's composition was depicted, at the time and in collective memory, as a "racial sample" from Brazil. This image of harmonious race relations also helped fuel the myth of racial democracy. The purpose of 
this article is to review the racial formation of the FEB, checking the available documentation in military archives and Brazilian civil and recent historiography. This study concludes that FEB, with slight differences, reproduced the racial structure of the Brazilian population in its composition. However, this "multiethnic and cultural melting pot" was an unplanned consequence of the recruitment process for the expeditionary division, since the objective of the Army authorities was to recruit an "elite", with criteria of physical health and literacy that could be exclusive for a part of the non-white youth. However, due to the difficulties of selective recruitment and the evasion of part of the middle and upper classes, predominantly white, it was sent to war a troop with racial and cultural origins which can be considered a kind of "sample" of Brazilian society. Keywords: Brazilian Expeditionary Force; Brazilian Army; Race relations; Racial democracy. 
A FEB era um bom resumo do povo do Brasil, não só porque tinha soldados de todos os seus estados e de todas as classes sociais e níveis de cultura, mas também porque levava todos os seus defeitos e improvisações, todas as suas incoerências e mitos, todas as falhas e virtudes desse povo.

Ruben Braga

Entre 1944 e 1945, o Brasil enviou um pequeno exército de 25 mil homens - a Força Expedicionária Brasileira (FEB) - para combater as forças do Eixo na Segunda Guerra Mundial. Uma das imagens mais notáveis da FEB foi a de ser o único exército combatente em toda a guerra, que foi racialmente integrado, sem distinções étnicas ou nacionais. Esta imagem de um “caldeirão de raças” como amostra da população brasileira, em proporção e relações raciais harmônicas, também ajudou a alimentar o mito da democracia racial. ${ }^{3} \mathrm{~A}$ memória coletiva do país retratou a FEB como uma tropa formada por um pequeno e mestiço Davi, ${ }^{4}$ que derrotou, nos campos de batalha da Itália, o Golias alemão da "Raça Superior”.

O objetivo principal deste artigo é reexaminar a formação racial da FEB, verificando a documentação disponível em arquivos militares e civis brasileiros e a historiografia recente. Em segundo plano, visa contribuir para a compreensão das relações raciais na FEB, como parte do processo histórico de mudança e permanência de questões de raça no Exército brasileiro como um todo, na primeira metade do século XX.

Este estudo é dividido em três partes. Depois de um breve exame do "estado da arte" deste tema, bem como das fontes usadas neste artigo, serão discutidas em segundo lugar a composição e as relações raciais no Exército antes da guerra, mais precisamente no Serviço Militar. Na terceira parte serão apresentados os resultados da pesquisa com a documentação disponível no momento, sobre o perfil racial da FEB.

\section{O Estado da Arte}

As tropas brasileiras enviadas à Campanha da Itália foram vistas pelo povo do país como uma amostra representativa e genuína da população brasileira, nas suas qualidades e problemas, com autoimagem de harmonia racial e ausência de discriminações. O papel desempenhado pela integração de brancos, mestiços, negros, asiáticos e descendentes de indígenas na FEB, para a construção do 
mito da democracia racial, foi um dos assuntos discutidos pelas duas principais obras sobre as relações raciais na divisão brasileira: os estudos de Oliveira e Maximiano (2001) e Rosenheck (2015) ${ }^{5}$. São estudos com objetivos e bases documentais ligeiramente diferentes. Oliveira e Maximiano concentram-se na comparação das relações raciais experimentadas pela divisão de infantaria da FEB e pela $92^{\text {a }}$ Divisão de Infantaria do Exército dos Estados Unidos ("Buffalo Division”). Essa divisão, que combateu no mesmo teatro de operações da FEB na Campanha da Itália - com suas subunidades substituindo-se mutuamente se caracterizou por ser segregada em termos raciais e era composta por praças negros e comandada por oficiais superiores brancos. ${ }^{6}$ Nessa comparação, eles procuram compreender a estruturação de unidades, racialmente integradas (FEB) e segregadas ( $92^{\mathrm{a}}$ Divisão), as consequências de tais relações raciais sobre o desempenho dessas divisões em combate e, finalmente, como a proclamada integração racial dos expedicionários teria sido mais um dos exemplos confirmatórios da alegada democracia racial brasileira (OLIVEIRA; MAXIMIANO, 2001, p. 156).

Uri Rosenheck, por sua vez, centra sua atenção nas relações raciais da FEB e como elas foram percebidas durante e após a guerra, abordando as relações segregadas da divisão “colored” americana e as percepções mútuas dessas unidades. Assim, o artigo procura entender a reflexão que tal encontro provocou e revelou nas relações raciais posteriores (ROSENHECK, 2015, p. 144).

As fontes documentais usadas por esses autores também são diferentes. Para a análise da questão racial na FEB, Oliveira e Maximiano selecionaram principalmente as memórias escritas e orais de ex-combatentes. Rosenheck (2015) também as usou, mas foi beneficiado pelo maior volume e variedade que os 14 anos decorridos da publicação de Oliveira e Maximiano proporcionaram. Além disso, também usou outras fontes, como jornais de ativistas afroamericanos e até mesmo histórias em quadrinhos sobre a participação brasileira na guerra, publicadas mais de uma década após o fim do conflito.

Nas conclusões, Oliveira e Maximiano (2001) e Rosenheck (2015) concordam em vários pontos: a) A FEB foi realmente integrada em termos raciais, e a comparação com a segregação existente na Buffalo Division deu uma imagem positiva à divisão expedicionária; $b$ ) Houve, contudo, alguns episódios de racismo na FEB, mas ocorreram principalmente durante o período de treinamento, ainda no Brasil. Ocorrências no Teatro de Operações da Itália foram raras e individualizadas; c) A autoimagem de uma tropa integrada contribuiu para reforçar, durante o período de guerra e no pós-guerra, o mito da democracia 
racial.

No entanto, as ênfases específicas de cada trabalho também devem ser destacadas. Oliveira e Maximiano (2001) enfatizam a crítica dos expedicionários brasileiros e dos comandantes americanos e britânicos sobre o desempenho da Buffalo Division, considerada deficiente em combate. Essa performance deficiente foi atribuída, principalmente pelos brasileiros, a um moral de combate baixo, como consequência da situação segregada das tropas americanas. No trabalho de Rosenheck (2015) a ênfase foi concentrada na força da imagem de integração racial da FEB, tanto durante a guerra (na autoimagem vivenciada pelos expedicionários e nas imagens da imprensa ativista afro-americana), como no período pós-guerra (na memória coletiva de FEB expressada em memórias tradicionais e outras fontes, como quadrinhos). Não obstante, o autor mostrou que as referências laudatórias não puderam esconder as contradições do mito da democracia racial, em todos os momentos do FEB e em sua memória.

\section{O problema da documentação}

Para as finalidades deste artigo, ou seja, para melhor entender se a composição da FEB foi realmente representativa da população brasileira e se as relações raciais na FEB reproduziram aquelas existentes no país, ou se foram diferentes, inicialmente deve-se entender como foi formada a FEB, a partir da base do Serviço Militar pré-guerra, e se o resultado dessa formação reproduziu a estrutura de distribuição racial no país.

Sobre a composição racial da FEB, especificamente, despontam três estudos, com dois tipos de fontes diferentes e, de certa forma, também diferentes conclusões. Dois desses estudos são baseados em um mesmo tipo de fonte documental: as cópias de Certificados de Reservistas dos expedicionários pertencentes ao Depósito de Pessoal da FEB (DP/FEB). ${ }^{7}$ Esses certificados continham uma série de dados de cada expedicionário, como nome, ano e local de alistamento, nome dos pais, data e local de nascimento, cor, cabelos, olhos, altura, nariz, rosto, sinais particulares, alfabetização, além de dados sobre o serviço ativo e folha de alterações. Uma particularidade dessas fichas é fundamental para os estudos sobre perfil racial da FEB: praticamente todas as fichas contêm retratos 3x4 dos praças registrados.

A primeira computação sistemática desses dados foi feita pela historiadora Patrícia da Silva Ribeiro (2013), para seu doutorado em História na Fundação 
Getúlio Vargas, Rio de Janeiro. A autora encontrou 1.166 cópias de certificados. Para a questão racial, Ribeiro notou que havia frequentes discrepâncias entre a "cor", atribuída na ficha, e aquela percebida no retrato $3 \times 4$. A alguns praças negros nas fotos era atribuída a "cor” parda. A alguns praças, com traços mestiços nos retratos, era atribuída a "cor" branca. Em face dessa situação, a autora preferiu tabular os fenótipos expressados nos retratos dos expedicionários, ao invés de fazê-lo com a cor declarada nas fichas. A partir desse procedimento, os resultados alcançados por Ribeiro foram os seguintes:

Tabela 1 - Cor de pele segundo os retratos das fichas do DP/FEB

\begin{tabular}{|c|c|}
\hline Cor da pele & Porcentagem \\
\hline Branca & $56,0 \%$ \\
\hline Preta & $20,0 \%$ \\
\hline Parda & $22,3 \%$ \\
\hline Amarela & $00,4 \%$ \\
\hline Sem foto & $00,3 \%$ \\
\hline
\end{tabular}

Fonte: Ribeiro (2013, p. 162).

Usando outra fonte documental, o estudo que Adriane Piovezan (2017) realizou para seu doutorado em História, publicado no livro "Morrer na Guerra: a sociedade diante da morte em combate", incluiu um levantamento do perfil racial da FEB, através dos Relatórios do Pelotão de Sepultamento da Divisão Expedicionária. Nesses documentos, a autora estava à procura de possíveis "variáveis étnicas nas atitudes e representações diante da morte" entre os expedicionários (PIOVEZAN, 2017, p. 66). Os Relatórios Individuais de Sepultamento registravam, entre outros dados, o item "raça". Os resultados do levantamento de Piovezan estão sintetizados na tabela abaixo:

Tabela 2 - Perfil racial dos mortos da FEB

\begin{tabular}{|c|c|c|}
\hline Raça & Número de mortos & Porcentagem \\
\hline Branca & 357 & $81,12 \%$ \\
\hline Preta & 62 & $14,09 \%$ \\
\hline Parda & 07 & $01,59 \%$ \\
\hline
\end{tabular}




\begin{tabular}{|c|c|c|}
\hline Morena & 06 & $01,36 \%$ \\
\hline Parda escura & 01 & $0,22 \%$ \\
\hline Indeterminada & 07 & $01,62 \%$ \\
\hline Total & 440 & $100 \%$ \\
\hline
\end{tabular}

Fonte: Relatórios do Pelotão de Sepultamento, AHEx, SAE, FEB (apud PIOVEZAN, 2017, p. 68).

Por fim, o terceiro estudo, desenvolvido em projeto de pesquisa coordenado pelo autor, e apresentado em evento científico pelos orientandos Victor Hugo Bento da Costa Traldi e Matheus Moreto Guisso Rodrigues (2017), utilizou as mesmas fichas usadas por Patrícia Ribeiro, mas com algumas diferenças significativas. A primeira delas foi a revisão individual das fichas, que resultou em encontrar dez repetições no lote documental do arquivo. Assim, o estudo analisou 1.156 fichas, e não 1.166, como no estudo anteriormente citado ${ }^{8}$. A segunda diferença consistiu em computar os dados relativos à "cor” exatamente como atribuídos no documento, independentemente da cor no retrato do expedicionário coincidir ou não com o que estava declarado no documento. Os resultados conseguidos foram diferentes dos obtidos nos dois estudos anteriormente citados.

Tabela 3 - Perfil dos expedicionários do $4^{\circ}$ e $5^{\circ}$ Escalões (DP/FEB), segundo a cor

\begin{tabular}{|c|c|}
\hline \multicolumn{2}{|c|}{ Ficha de Reservistas do $4^{\circ}$ e $5^{\circ}$ Escalões da FEB } \\
\hline Brancos & $64,5 \%$ \\
\hline Pretos & $05,3 \%$ \\
\hline Pardos & $27,3 \%$ \\
\hline Amarelo & $0 \%$ \\
\hline Sem informação & $02,9 \%$ \\
\hline Total & $100 \%$ \\
\hline
\end{tabular}

Fonte: Rodrigues e Traldi (2017, p. 1624).

As diferenças entre as tabelas são marcantes. Entre os classificados como "brancos", o levantamento de Piovezan (2017) encontrou 81,12\%, enquanto a análise das fichas de reservistas utilizadas em Ribeiro (2013), registrou 56\% e a 
de Rodrigues e Traldi (2017), encontrou 64,5\%. A soma de "pardos" (inclusive denominações como "morena" e "pardo-clara") e negros, em Piovezan, é de $17,26 \%$, enquanto Rodrigues e Traldi totalizam 32,60\% (ou seja, quase o dobro daquela encontrada em Piovezan), e o levantamento de Ribeiro (2013) totalizou 43,7\%. A maior diferença é, contudo, nos resultados referentes aos expedicionários negros da FEB. Ribeiro (2013) registrou 20\% de negros, Piovezan 14,09\%, enquanto Rodrigues e Traldi computaram 5,3\%, ou seja, quase um terço do resultado encontrado na amostragem dos mortos da FEB, e um quarto do levantamento com as mesmas fichas, feito por Ribeiro (2013).

Para a discussão dos porquês de diferenças tão expressivas nos três levantamentos, é necessário entender a natureza das duas amostragens e as formas pelas quais cada documentação foi produzida. Para tanto, deve-se chamar a atenção ao caráter fragmentado e incompleto das fontes documentais disponíveis sobre esse assunto. Não há arquivos centralizados para a Força Expedicionária Brasileira. O Arquivo Histórico do Exército, no Rio de Janeiro, possui apenas a documentação das unidades da FEB que foram extintas. Parte da documentação está localizada nas unidades militares da FEB ainda em serviço espalhadas por todo o país, em diferentes condições de acesso e conservação.

Em relação ao perfil dos expedicionários (étnico, profissional, físico, grau de instrução, origens geográficas, etc.), o problema se agrava, pois não há uma documentação específica sobre esses dados - ou pelo menos não está acessível e/ou organizada para consulta em arquivos militares. O pesquisador desse perfil depende de amostragens, com todas suas imperfeições. Esse é o caso das duas séries citadas anteriormente - os Relatórios Individuais do Pelotão de Sepultamento da FEB (444 documentos) e as 1.156 Fichas de Reservista do Depósito de Pessoal da FEB (DP/FEB). Sobre essas séries estatísticas, alguns pontos necessitam ser destacados. Um deles é a natureza da amostragem. A autora de Morrer na Guerra, ao pesquisar a documentação do Pelotão de Sepultamento da FEB, encontrou, nos Relatórios Individuais de Sepultamento, dados importantes sobre o perfil étnico da FEB, ou pelo menos, do grupo de mortos, como nome, posto, unidade, arma ou serviço, endereço, "raça", dados sobre a morte, estado do corpo, objetos pessoais, etc. É um conjunto precioso de informações. No entanto, exatamente por causa da natureza específica do grupo documentado, é preciso ter cautela para considerar a estatística dos mortos da FEB como uma amostragem representativa da FEB como um todo. Das 444 mortes reportadas até 25 de junho de 1945, aquelas em combate somaram 321 (72,3\%). Assim, unidades combatentes da infantaria concentraram o 
contingente de mortos, seguidos muito de longe pela Artilharia, Engenharia e Batalhão de Saúde. Há uma desproporção entre o contingente de mortos em combate e o de membros das diversas unidades que compuseram a FEB?

Há uma outra desproporção, esta apontada por Piovezan. Comparando os dados do PS/FEB com a proporção racial presente no Censo de 1940, a autora chama a atenção para a diferença entre os dados - 63,65\% de brancos para o Censo contra 81,12\% do PS/FEB. Piovezan aponta para os esforços de "branqueamento" no processo de preenchimento dos relatórios, baseada nas práticas semelhantes reportadas por recenseadores do levantamento de 1940. Contudo, essa hipótese, como a própria autora reconhece, carece de mais elementos inequívocos para ser confirmada (PIOVEZAN, 2017, p. 71-72).

Por sua vez, as cópias do Certificado de Reservista de $1^{\text {a }}$. Categoria, utilizadas no levantamento realizado por Rodrigues e Traldi (2017), são originadas do DP/FEB, que foi criado para substituições das unidades desfalcadas por baixas e transferências durante a guerra. Dessa unidade, a documentação acessível registra uma amostragem composta por fichas individuais de praças (soldados, cabos, sargentos e subtenentes). Essa unidade foi, basicamente, formada por homens que embarcaram nos dois últimos escalões da FEB, o $4^{\circ}$ e o $5^{\circ}{ }^{10}$. Desse contingente de 9.773 expedicionários, 3.379 substituíram os claros na Divisão Expedicionária. É importante notar que nem todos os que embarcaram nesses últimos escalões foram encaminhados para substituição, após período de treinamento. Por volta de um terço desse contingente foi encaminhado "aos trabalhos de instrução, vida e administração desse órgão de retaguarda" (MORAES, 1947, p. 61). Assim, essa amostragem reúne tanto expedicionários combatentes ou aptos para substituírem as baixas em campanha quanto aqueles que deveriam ficar nos serviços, na retaguarda, na condição de nãocombatentes, bem como expedicionários que fizeram o treinamento de combate na Itália, mas não foram destacados para ação até o final da guerra.

Há muitas dúvidas sobre o perfil físico e regional desses dois últimos escalões. Como será visto adiante, havia uma postura inicial das autoridades militares em concentrar os jovens com melhores resultados nos exames físicos, psicológicos e com melhor instrução, para os primeiros escalões. No entanto, não há documentação conhecida que comprove que, efetivamente, os três primeiros escalões embarcados tinham um perfil diferente daqueles dois últimos. Assim, enquanto não for ampliado o corpus documental, essa amostragem detalhada das fichas que seriam base para os Certificados de Reservista da FEB deve continuar sendo a base mais confiável para o perfil étnico da FEB. 


\section{Fontes sobre o Serviço Militar pré-Segunda Guerra}

Para entender melhor se a FEB constituiu ou não uma amostra razoavelmente precisa da configuração racial brasileira na época da Segunda Guerra Mundial, é importante ver como era essa configuração racial nos anos anteriores à guerra. A base para convocação, recrutamento e seleção para a FEB foi o registro do Serviço Militar. Como no caso de fontes da FEB, os dados também são fragmentados e incompletos. Assim, será utilizada a pesquisa feita pelo coronel médico Arthur Lobo da Silva, realizada com uma amostra nacional de 38.560 recrutados no Serviço Militar em todos os estados do país, entre 1922 e 1923 e publicado em 1928. Apesar da diferença de 20 anos entre o momento em que esses dados foram coletados e o recrutamento para a guerra, esse levantamento ainda é a melhor fonte disponível para os dados do recrutamento do Serviço Militar.

Finalmente, todos esses dados devem ser comparados com a série estatística do Censo Brasileiro de 1940. No item “cor”, o Censo fornece estatisticamente os dados pela nação como um todo, por estados da federação, por idades e gênero, entre outras informações. Para comparar os dados sobre o Serviço Militar e a amostra de FEB foi escolhida a coorte de homens de 20 a 29 anos, a mais próxima da idade militar dos expedicionários.

Há um ponto importante que deve chamar nossa atenção sobre questões referentes à “raça” entre o Censo, o Serviço Militar e os dados do DP/FEB FEB: a origem da informação racial. No caso do Serviço Militar e da FEB, não há informações confiáveis sobre se os dados raciais foram fornecidos pelos próprios entrevistados ou se foram atribuídos por soldados destacados para preencher esses dados dos praças para o Exército. O Censo de 1940 também deixou dúvidas sobre a forma como as informações do item "cor" foram coletadas. Todas essas preocupações sobre quais métodos foram usados para a coleta dos dados são justificadas porque, nas questões raciais brasileiras, existem dúvidas relevantes sobre o esforço de branqueamento da população não-branca. Alguns dos espaços disponíveis em que os esforços de branqueamento funcionam são o Censo e pesquisas que procuram definir quem é branco e quem não é branco entre a população. Foi observado, pelos recenseadores do Censo de 1940, que havia esforço, por parte de uma parcela de não-brancos, em declarar-se "branco" ou "pardo". No caso das Fichas de Reservista dos expedicionários, foram observados frequentes casos em que a fotografia do praça mostrava uma “cor” e o dado declarado mostrava outra. Mestiços declaravam-se "brancos” 
e negros declaravam-se "pardos", com variações que oscilavam entre "pardo escuro", "moreno escuro", "pardo", "moreno”, "moreno claro”, "pardo claro", etc. Uma explicação possível para essas estratégias usadas por pessoas das populações negras e pardas, para se tornarem tão "brancas" quanto possível, é a de que tais expedientes poderiam representar mais chances de emprego e reconhecimento social, numa sociedade em que a cor da pele fazia, sim, diferença (PIZA; ROSEMBERG, 1999; SCHWARCZ, 2012, p. 97-106).

Outras fontes que foram usadas neste artigo são os Relatórios Anuais do Ministério da Guerra, os periódicos dirigidos ao público majoritariamente militar (Revista Militar Brasileira, Revista de Intendência, A Nação Armada), outros documentos do Arquivo Histórico do Exército e, por fim, mas não menos importante, o já citado Censo Demográfico Brasileiro de 1940 (IBGE, 1950). O estudo dessas fontes mostrou que, antes de analisar a convocação, seleção e incorporação de jovens civis para a FEB, deve-se entender como funcionava tal recrutamento em tempos de paz, e qual era o perfil étnico do Exército Brasileiro pré-Segunda Guerra Mundial.

\section{Serviço Militar e questão racial no periodo entre-guerras}

Desde a instituição do Serviço Militar obrigatório a partir de 1916, as lideranças militares estavam preocupadas com a qualidade do material humano a mobilizar em caso de necessidade. O Sorteio Militar significaria uma amostra aleatória da sociedade brasileira, e essa sociedade mostrou uma situação preocupante: analfabetismo, saúde precária, graves disparidades regionais, baixíssima motivação para o recrutamento militar. Além desses problemas, houve dificuldades institucionais em alistar e recrutar pessoas em áreas rurais e, acima de tudo, a prática constante de evasão do Serviço Militar de jovens das classes urbanas médias e ricas.

Persuadir as classes mais ricas e educadas a deixar seus rapazes no quartel para o Serviço Militar era uma tarefa inglória. A fama do Serviço Militar era a de que os soldados eram mal alimentados, submetidos a punições físicas e os quartéis, insalubres. Para piorar as coisas, as doenças faziam parte do cotidiano dos recrutados. Relatórios do estado de saúde do Exército no início da década de 1940 mostravam que parasitas, doenças tropicais, respiratórias e venéreas retiravam recrutas das instruções e exercícios e os baixavam em hospitais militares (SILVA, 1940, p. 19-32). Nas décadas anteriores à Segunda Guerra Mundial, o Exército tentou resolver esta situação com a remodelação 
das instalações militares, a melhoria do Serviço Médico do Exército e dando grande atenção à Educação Física Militar. Para selecionar e melhorar o material humano a ser mobilizado pelo Exército, foi criado um serviço biométrico. Suas práticas e suas medidas instrumentais tinham caráter eugênico, mas seu foco não era excluir "raças inferiores", era antes "aperfeiçoar o homem brasileiro" (GOMES; SILVA; VAZ, 2013, p. 1551-1569; SILVA, 1928, p. 15-16; PIERO, 1944).

No entanto, independentemente de quanto progresso foi feito com o conhecimento sobre a melhoria das massas mobilizadas para o serviço militar, ainda havia concepções muito profundas e pessimistas sobre a natureza do homem brasileiro. Nas duas primeiras décadas do século XX, para vários grupos de elites militares e civis, os problemas do contexto histórico, social e económico do país eram relacionados com considerações negativas sobre a natureza do povo brasileiro e essas tinham uma motivação predominantemente racial. A resposta mais fácil desses intelectuais civis e militares foi associar as razões dos atrasos do desenvolvimento brasileiro à miscigenação da população do país. A solução, é claro, foi o "branqueamento", a europeização da população, a ser alcançada com a atração de imigrantes europeus. No entanto, após a Primeira Guerra Mundial, esse modo de pensamento declinou, principalmente devido ao surgimento de novas gerações de pensadores que se recusaram a apontar a miscigenação ou inferioridade racial como o principal motivo para os problemas brasileiros (D’ÁVILA, 2003, pos. 199/5310). Ao contrário da eugenia racista que ainda tinha sucesso relativo na Europa e nos Estados Unidos, a eugenia então predominante no Brasil não era excludente, sendo sua missão interpretada como higiene social, uma melhoria da nação através da luta contra os fatores considerados prejudiciais à saúde da população (D’ÁVILA, 2003, pos. 449/5310; MELO, 1946, p. 18-19; STEPAN, 2005, p. 48-52). Os problemas de saúde e educação do país deveriam ser resolvidos, portanto, com a disseminação da educação, saúde pública e fortalecimento físico (SKIDMORE, 2012, p. 233-235).

Com o surgimento do nazismo na Europa e suas formas violentas de exclusão racial, as teorias do racismo científico deixaram de encantar as elites brasileiras. Não obstante, essas elites mantiveram sua crença no crescente "branqueamento" do país. Contudo, essa crença não poderia mais se basear na superioridade ou inferioridade racial, mas em uma "integração étnica" bem sucedida, na qual os problemas desapareceriam com a dissolução progressiva das diferenças raciais, devido ao processo de "purificação" da população ao longo da gerações. Essa opinião foi compartilhada por vários oficiais militares do exército brasileiro. Antes de embarcar com a FEB, um deles, o coronel do 
Exército Francisco de Paula Cidade, escreveu uma introdução à publicação das memórias de Carl Seidler, um soldado mercenário alemão, que serviu nas tropas imperiais brasileiras nas primeiras décadas do século XIX. Paula Cidade não escondeu o alívio, ao “corrigir” a previsão de Seidler e outros europeus, que predisseram que o Brasil se tornaria um “império dos negros”. Para o coronel, "falharam, porém, os sombrios prognósticos dos velhos escritores e viajantes". A “condenada corrente preta” foi substituída "pelo melhor sangue branco" (PAULA CIDADE, 2003, p. 15, 21).

Paula Cidade não estava sozinho na crença do branqueamento crescente do país. O coronel-médico Arthur Lobo da Silva, ao analisar os resultados estatísticos do Serviço Militar, também observou, como uma tendência inexorável, que a população branca estava se tornando, cada vez mais, a majoritária na população do país (SILVA, 1928, p.18, 1941, p. 48-55). Uma opinião semelhante foi expressada, após a Segunda Guerra Mundial, pelo comandante da Artilharia da FEB, general Cordeiro de Farias, o qual dizia que, apesar da característica principal do povo brasileiro ser a mestiçagem racial, poderia ser verificada “a predominância de elementos europeus nesse melting pot, o que nos trouxe a cultura europeia, no passado, e nos arrasta uma cultura norte-americana hoje em dia”. ${ }^{11}$. De acordo com esse ponto de vista, o Brasil estava trabalhando para a solução de seu problema racial: a miscigenação diminuía, o país estava se tornando "branco" e a democracia racial funcionava. O problema a ser desafiado pelo país não seria, portanto, racial, mas as doenças e o analfabetismo. Nessa perspectiva, o Serviço Militar, por seu alcance em todo o país e seus esforços para melhorar seus ideais de saúde e educação da juventude, deveria desempenhar um papel fundamental na reconciliação da nação brasileira com seu potencial.

No entanto, se as declarações retóricas insistiam para descrever o "branqueamento" do Brasil, os dados estatísticos anteriores à Segunda Guerra Mundial mostravam que, pelo menos no Serviço Militar, a proporção racial ainda se mantinha quase a mesma (tabela 4).

Tabela 4 - Composição racial da população masculina brasileira em idade de recrutamento, na população total (Censo de 1940) e no Serviço Militar

\begin{tabular}{|c|c|c|c|}
\hline \multicolumn{1}{|c|}{ Item "Cor" } & \multicolumn{1}{c}{$\begin{array}{c}\text { Censo/1940: Idade } \\
\text { entre 20 e 29 anos }\end{array}$} & $\begin{array}{c}\text { Censo/1940 } \\
\text { População total }\end{array}$ & $\begin{array}{c}\text { Serviço Militar } \\
\text { Amostra de 1922-1923 }\end{array}$ \\
\hline Brancos & $63,65 \%$ & $63,47 \%$ & $59 \%$ \\
\hline Pardos & $21,02 \%$ & $21,28 \%$ & $31 \%$ \\
\hline
\end{tabular}




\begin{tabular}{|c|c|c|c|}
\hline Negros & $14,60 \%$ & $14,66 \%$ & $10 \%$ \\
\hline $\begin{array}{c}\text { Amarelos/Sem } \\
\text { informação }\end{array}$ & $0,73 \%$ & $0,69 \%$ & - \\
\hline
\end{tabular}

Fonte: IBGE (1950, p. 6); Silva (1928, p.48).

Outros grupos de oficiais do Exército, no entanto, não estavam preocupados com o "branqueamento" da jovem coorte masculina, mas com sua melhoria através de ações sanitárias e educacionais. A maioria dos médicos militares do Exército, nas primeiras décadas do século XX, disseminou na instituição a ideia de "melhoria corporal" de forma não excludente. Serviço militar, práticas de higiene, exercício físico, iniciativas de alfabetização se destinavam a melhorar indivíduos e criar soldados fisicamente robustos e com melhor desempenho intelectual (BEATTIE, 2001, p. 254-255; D’ÁVILA, 2003, pos. 909/5310; FALCÃO, 2012, p. 92-93). De acordo com esses oficiais médicos, os primeiros resultados mensuráveis do serviço militar mostraram que o fortalecimento da população brasileira jovem seria mais eficiente se esse serviço fosse mais abrangente. Um capitão-médico chegou a argumentar que a transformação dos recrutas em soldados saudáveis acabaria com qualquer pessimismo devido às teorias eugênicas do passado, que insistiam em associar miscigenação a uma condenação do "homem brasileiro" ao fracasso (ANDRADE, 1940, p. 105-106).

Por outro lado, enquanto os médicos militares evitavam qualificar no respeitante à raça o "soldado brasileiro" como fisicamente fraco e sem instrução, investindo no Serviço Militar como fator de fortalecimento geral, vários oficiais superiores do Exército Regular eram mais pessimistas a respeito do material humano recrutado. ${ }^{12}$ Trazendo em mente as concepções aprendidas nas escolas militares e nas experiências de início de carreira, nas décadas de 1910 e 1920, esses oficiais superiores reproduziam, frequentemente, a maneira de pensar ainda marcada por princípios eugênicos excludentes, que associavam negativamente certas regiões, climas e níveis civilizatórios com degenerações de origem racial ${ }^{13}$.

A distribuição racial em todo o país não era equilibrada. As regiões norte e nordeste concentraram uma maioria de pardos e negros, em comparação com os brancos. Essas regiões foram as mais criticadas pelo ministro do Exército ${ }^{14}$, pelo que ele entendeu como um sinal da fraqueza das tropas recrutadas no Serviço Militar (tabela 5). 
Tabela 5 - Perfil de recrutados do Serviço Militar, amostra de 1922-1923, por região de federação e por raça (em porcentagem)

\begin{tabular}{|c|c|c|c|}
\hline Região & Brancos & Negros & Pardos \\
\hline Norte & $34,19 \%$ & $6,81 \%$ & $59,00 \%$ \\
\hline Nordeste & $36,39 \%$ & $12,57 \%$ & $51,04 \%$ \\
\hline Sul & $64,22 \%$ & $09,96 \%$ & $25,82 \%$ \\
\hline Sudeste & $78,10 \%$ & $05,75 \%$ & $16,15 \%$ \\
\hline Centro-Oeste & $42,10 \%$ & $09,95 \%$ & $47,95 \%$ \\
\hline
\end{tabular}

Fonte: Arthur Lobo da Silva (1928).

Foi em meio a tais dúvidas sobre a capacidade de combate do "povo brasileiro", que a seleção dos conscritos foi organizada para compor a Força Expedicionária Brasileira. De certa forma, desde a organização do Sorteio Militar, o recrutamento em tempo de paz já fazia uma seleção anterior, de forma a se registrar como reserva militar da nação apenas os jovens com um mínimo de índices físicos e intelectuais. A exigência do Registro Civil também afastou alguns grupos sociais de recrutamento. Sem esse documento, os jovens do campo e lugares distantes não poderiam ser alistados e ser recrutados. Assim, o próprio processo de alistamento seria responsável por reunir mais pessoas das áreas urbanas do que das áreas rurais e mais pessoas de cidades atendidas por redes de transporte acessíveis do que aquelas cujas chamadas de recrutamento dificilmente poderiam chegar ao convocado (SILVA, 1928, p. 2324; MAXIMIANO, 2010, p. 59-61).

Comparando-se os dados de proporção racial do Censo Demográfico de 1940 e os compilados pelo coronel Silva (1928), pode-se verificar que há uma ligeira diferença entre a proporção racial observada no Serviço Militar e a observada na sociedade brasileira em geral - os resultados apresentam mais pessoas brancas na população em geral do que no Serviço Militar (63,65\% e $59 \%$, respectivamente) e mais pardos e negros recrutados do que os que se encontram na população em todo o país (respectivamente, 35,62\% e 41\%).

$\mathrm{O}$ que poderia explicar esses números, se o processo de recrutamento e seleção física excluísse naturalmente, mais pessoas de regiões com menor desenvolvimento urbano e sanitário (com a maior proporção de negros e pardos) do que de áreas mais urbanizadas e de acesso mais fácil à saúde pública 
e à instrução? Lobo da Silva fornece uma explicação: desde o início do Serviço Militar obrigatório, famílias de classe média e alta, predominantemente brancas, usaram todos os recursos sociais que tinham em mãos para livrar seus filhos do "tributo de sangue":

Preciso notar que considerável número de indivíduos que frequentam collegios e escolas superiores, ficam isentos do serviço militar obrigatorio, por terem tirado alli a caderneta de reservistas, depois de feito o curso especial de instrucção militar. É notorio que a quasi totalidade desse enorme contingente sáe da camada de brancos, diminuindo assim a relativa proporção no computo geral no que respeita á raça branca. (SILVA, 1928, p. 19).

Assim, as chances do Exército poder contar, em suas fileiras, com o grupo de melhor acesso à saúde, alimentação e educação eram prejudicadas pela fuga das elites ao Serviço Militar. Aqueles que, pertencendo ao grupo branco, não possuíam ou não utilizavam as relações clientelísticas, para escapar ao "tributo de sangue”, acabavam incluídos nas fileiras dos recrutáveis. E aí, um fenômeno curioso foi reportado por Silva (1940): nas estatísticas do Serviço Militar Regular das décadas anteriores, o percentual de recrutados considerados aptos pelas Juntas Médicas mostrara que os examinados "brancos" obtiveram os piores resultados (71\% aptos), comparado com os "mestiços" (77\% aptos), "pretos" (80\% aptos) e "caboclos" (81\%). Para tais medições, o índice de robustez física utilizado pelos médicos militares brasileiros foi o "Índice de Pignet". Esse índice foi criado pelo médico militar francês Maurice-Charles-Joseph Pignet (1871-1935); consistia em uma equação na qual as variáveis eram a altura, o peso e o perímetro toráxico. Com os dados do levantamento efetuado na década de 1920 em mãos, Silva (1928) já havia questionado as crenças comuns da "inferioridade" dos mestiços e negros brasileiros, citando um trabalho de outro médico (Romeiro da Rosa): “É interessante ressaltar que o índice dos mestiços, cuja inferioridade physica é tão decantada, seja superior ao dos brancos, pelo menos na região onde fizemos as presentes observações" (Apud SILVA, 1928, p. 33). Anos depois, em outro estudo, Lobo da Silva comentou que uma das explicações para os examinados brancos terem chegado ao Serviço Militar com resultados piores que seus pares negros e pardos, era o fato de que esses dois últimos grupos desempenhavam, por ocasião dos exames físicos, 
“as profissões mais penosas (serviços de roças, de carretos, etc) [...] ao passo que as profissões mais sedentárias (comércio, empregados públicos, profissoes liberais, estudantes) são predominantes nos indivíduos de raça branca (SILVA, 1941, p. 55)”. Como, após um ano de Serviço Militar, o grupo “branco” tenha sido aquele que mais ganhara robustez física, o medico militar concluía ressaltando os benefícios do Serviço Militar para o preparo de jovens no exército brasileiro (SILVA, 1941, p. 57).

Em suma, o Serviço Militar, principal base para a seleção das tropas a serem enviadas para uma guerra hipotética, não evitava negros nem pardos. Pelo contrário, havia uma proporção ligeiramente maior de negros e pardos nas fileiras do Serviço Militar Regular do que na população como um todo. Isso sugere que, mesmo antes da mobilização para a Segunda Guerra Mundial, as práticas das classes superiores, (principalmente brancas) para escapar do recrutamento, já prejudicavam os esforços da instituição militar, na busca de democratizar o "tributo de sangue" igualmente para todas as classes sociais e todas as etnias, que compunham a população brasileira. Foi a partir dessas bases que se fez a seleção para a formação das Tropas Expedicionárias.

\section{Uma tropa de elite: os filtros de seleção}

Quando planejaram a formação das unidades expedicionárias para combater no exterior, as autoridades militares não tinham como principal objetivo a integração racial, mas sim selecionar para o Corpo Expedicionário os 3\% melhores do total da população masculina em idade militar - cerca de 60.000 homens em 2 milhões. Tratava-se de levar jovens a uma guerra mortífera, e não de fazer diplomacia ou propaganda da democracia racial. No entanto, dadas as condições sociais do Brasil, na década de 1940, é natural que um processo seletivo com critérios de melhor saúde e educação levaria o Exército a escolher os jovens de classes sociais com maior acesso a esses benefícios. Assim, recrutar uma elite com tais padrões deveria, involuntariamente, dirigir a composição da Força Expedicionária para um grupo mais caucasiano do que o negro ou o pardo. Outra maneira que poderia contribuir para "selecionar" uma elite com um perfil mais europeu seria a concentração (mais de $82 \%$, na composição final da FEB) daqueles selecionados das regiões sul e sudeste, cujos estados eram caracterizados por uma forte imigração europeia. Como resultado, todos esses padrões poderiam funcionar como filtros e, naturalmente, tenderiam a diminuir a proporção de negros e pardos da tropa selecionada, não diretamente 
devido à cor da pele, mas devido ao acesso historicamente desigual - entre esses grupos raciais - à educação e às condições de saúde em todo o país, que sempre estavam mais ao alcance dos brancos do que dos negros e dos pardos.

Antes, porém, de se verificar se os objetivos do processo de seleção para a FEB foram alcançados (os jovens com melhores aptidões físicas e intelectuais), devemos verificar se os critérios de seleção para a FEB seriam, mesmo que indiretamente, racialmente excludentes.

\section{A seleção física e intelectual e o choque da realidade}

Como já foi dito, para criar e moldar uma Força Expedicionária para o combate no exterior, as lideranças do Exército Brasileiro atuaram para selecionar uma “tropa de elite”, entre a juventude do país. Isso significa selecionar os recrutas que apresentassem o melhor desempenho em critérios físicos e intelectuais: altura minima de 1,60 centímetros, peso mínimo de $60 \mathrm{~kg}$, pelo menos 26 dentes naturais, audição normal, visão binocular, sentido cromático normal, equilíbrio mental e emocional e idade mental igual ou superior a dez anos de idade (GONÇALVES, 1951, p. 67-68).

Além desses critérios, o Exército tentou evitar, ao máximo, o recrutamento de analfabetos para a FEB. Com o objetivo de evitar que a FEB recrutasse analfabetos, o ministro da Guerra Eurico Dutra foi categórico:

Não há lugar para analfabeto nos exércitos regulares de hoje. [...] Os armamentos modernos utilizados em quaisquer das armas [...] requerem, da parte do soldado, um grau de desenvolvimento intelectual que o habilite, não só a conhecer-lhes o manejo, às vezes difícil e complicado, mas também, a agir por iniciativa própria quando se criarem situações que ele por si mesmo, e prontamente, haja de resolver. Eis aí a razão porque o aviso requer do candidato à admissão como voluntário a posse, no mínimo, de [...] instrução primária. Poderá revelar-se bravo aquele que não a possuir; mas não há dúvida que lhe faltarão, apesar disso, essenciais atributos de soldado" (FALA..., 1943, p. 2).

O que poderia ser uma preocupação natural, obrigatória em todos os exércitos com base no recrutamento civil (sorteio ou recrutamento), era no Brasil uma dor de cabeça para as autoridades militares, dados os resultados que mostravam 
as dimensões da fraqueza e deficiências de saúde pública e educação no país inteiro. Dos inspecionados, aqueles considerados física e intelectualmente aptos a pertencer às Tropas Expedicionárias estavam numa proporção muito aquém da desejada (GONÇALVES, 1951, p. 77-78).

A redução dos níveis de exigência dos exames, assim como a revisão dos resultados das incapacidades, foram as soluções possíveis. Ainda assim, 23.236 reprovações foram mantidas, de um total de 107.609 inspeções de saúde (GONÇALVES, 1951, p. 117-118). Esses resultados dos exames médicos exibiram uma imagem assustadora das condições sanitárias da população brasileira. Mostraram que, em áreas militares do Norte e Nordeste, o volume de rejeições era muito maior que o aceitável. O mais surpreendente, porém, foi verificar também taxas alarmantes na $4^{\text {a }}$ Região Militar (Minas Gerais) e na $5^{\text {a }}$ Região Militar (Paraná e Santa Catarina). De todos os examinados do país, no final de 1943 , apenas 59,50\% foram considerados capazes, conforme mostrado na tabela 6.

Tabela 6 - Resultados da Seleção Física inicial para unidades expedicionárias

\begin{tabular}{|c|c|}
\hline $\begin{array}{c}\text { Regiões Militares (Estados da } \\
\text { Federação) }\end{array}$ & Porcentagem de Incapazes \\
\hline $1^{\mathrm{a}} \mathrm{RM}(\mathrm{RJ} / \mathrm{DF})$ & $32,2 \%$ \\
\hline $2^{\mathrm{a}} \mathrm{RM}(\mathrm{SP} / \mathrm{GO})$ & $24,3 \%$ \\
\hline $3^{\mathrm{a}} \mathrm{RM}(\mathrm{RS})$ & $33,1 \%$ \\
\hline $4^{\mathrm{a}} \mathrm{RM}(\mathrm{MG} / \mathrm{ES})$ & $77,0 \%$ \\
\hline $5^{\mathrm{a}} \mathrm{RM}(\mathrm{PR} / \mathrm{SC})$ & $64,5 \%$ \\
\hline $6^{\mathrm{a}} \mathrm{RM}(\mathrm{BA} / \mathrm{SE})$ & $39,7 \%$ \\
\hline $7^{\mathrm{a}} \mathrm{RM}(\mathrm{AL}, \mathrm{PE}, \mathrm{PB}, \mathrm{RN})$ & $65,3 \%$ \\
\hline $8^{\mathrm{a}} \mathrm{RM}(\mathrm{AM} / \mathrm{PA})$ & $77,2 \%$ \\
\hline $9^{\mathrm{a}} \mathrm{RM}(\mathrm{MT})$ & $52,0 \%$ \\
\hline $10^{\mathrm{a}} \mathrm{RM}(\mathrm{CE}, \mathrm{PI}, \mathrm{MA})$ & $56,4 \%$ \\
\hline
\end{tabular}

Fonte: Brasil (1944, p. 33).

Levando-se em consideração que o que é importante analisar, no que concerne à raça, é a proporção que potencialmente seria considerada, se isolarmos os dados estatísticos dos reservistas considerados aptos, constataríamos que 
seriam privilegiadas as regiões da população majoritariamente branca na composição da FEB.

Tabela 7 - Proporção da contribuição regional de jovens considerados aptos para as unidades expedicionárias na Seleção Física inicial

\begin{tabular}{|c|c|}
\hline Região & Proporção (\%) \\
\hline Sul & $7,97 \%$ \\
\hline Sudeste & $82,05 \%$ \\
\hline Centro-Oeste & $0,44 \%$ \\
\hline Norte & $1,84 \%$ \\
\hline Nordeste & $7,70 \%$ \\
\hline
\end{tabular}

Fonte: Brasil (1944, p. 33).

Verifica-se, portanto, que as unidades expedicionárias foram selecionadas com preferência em algumas regiões militares/estados da federação, em detrimento de outros. As lideranças militares justificaram essa escolha por duas razões, basicamente: pelo melhor estado de saúde das unidades escolhidas e pela necessidade de manter a proteção das regiões norte e nordeste com tropas que estavam estacionadas lá. Os estados com a maior proporção das Tropas Expedicionárias ainda eram os do Sudeste e do Sul (90,02\% após os exames físicos e intelectuais, 82,71\% do total de praças da FEB que realmente foram enviados para a Campanha da Itália) e a seleção da FEB teve a tendência de recrutar menos pardos e negros do que o seria, se o recrutamento fosse proporcional ao número do Serviço Militar. Infelizmente, os dados de seleção física são confusos - há diferenças entre os números apresentados no Relatório do Ministro da Guerra e os do Relatório do Chefe do Serviço Médico da FEB. Mas, ainda que se considere uma diferença de $8 \%$ de oscilação nas estatísticas da seleção física para o pessoal recrutado da região sul e sudeste, pode-se ter uma dimensão do impacto do local de recrutamento e do perfil racial da FEB. Por outro lado, se isolarmos apenas os dados indiscutíveis, uma comparação das proporções regionais entre os recrutados para o Serviço Militar (base para qualquer tipo de recrutamento) e os dados oficiais dos estados de origem dos praças que pertenceram à FEB e participaram da Campanha da Itália, podem ser alcançados os seguintes resultados: 
Tabela 8 - Comparação das contribuições regionais de recrutamento, entre aquele para o Serviço Militar e aquele para a FEB (total)

\begin{tabular}{|c|c|c|}
\multicolumn{1}{|c}{ Região } & Serviço Militar & FEB (total) \\
\hline Norte & $04,47 \%$ & $01,59 \%$ \\
\hline Nordeste & $24,07 \%$ & $12,63 \%$ \\
\hline Centro-Oeste & $00,44 \%$ & $03,39 \%$ \\
\hline Sudeste & $50,42 \%$ & $64,01 \%$ \\
\hline Sul & $20,10 \%$ & $18,38 \%$ \\
\hline
\end{tabular}

Fonte: Moraes (1947, p. 304); Silva (1928, p. 49).

Ao final da guerra, foi / é possível verificar a disparidade de contribuição para a formação de tropas expedicionárias por algumas regiões: o Norte contribuiu para a FEB com $1 / 3$ do recrutamento regular, a região nordeste com metade dos recrutados em tempo de paz. Em contraste, a contribuição da região centrooeste foi sete vezes maior do que a contribuição regular (devido à inclusão do $9^{\circ}$ Batalhão de Engenharia de Combate, de Aquidauana, Mato Grosso, na FEB). A região sudeste, que no Serviço Militar Ordinário incorporava cerca da metade dos conscritos, contribuiu com $2 / 3$ de todo o contingente da FEB.

Se a seleção física e as diferenças raciais regionais já tenderiam a produzir uma Força Expedicionária mais "branca" do que a média nacional, os requisitos de alfabetização, embora não explícitos no processo de seleção, também devem ser levados em consideração. Como os dados do Censo Demográfico mostram que a proporção de analfabetismo era muito mais significativa entre os negros e os pardos, deve-se verificar se um possível requisito de alfabetização seria capaz de induzir, mesmo que involuntariamente, uma seleção racial. Deve-se lembrar que, com exceção dos voluntários, a necessidade de alfabetização não foi explicitamente estabelecida pelo Ministério da Guerra como um critério de exclusão, conquanto a documentação indiretamente se refira à necessidade de instruções mínimas para a adesão em unidades expedicionárias. Essas referências mencionam a necessidade de que soldados selecionados tivessem instrução suficiente para desempenhar funções, como a leitura de instruções e sinais, guiar-se por mapas, etc. Mesmo com tal requisito informal, foi possível encontrar soldados iletrados na composição da FEB, não obstante em proporção radicalmente menor do que a média brasileira da década de 1940. A partir da 
realidade brasileira, no momento da seleção para as unidades expedicionárias, temos os seguintes dados:

Tabela 9 - Alfabetização da população masculina brasileira em idade militar (\%) (Censo de 1940)

\begin{tabular}{|c|c|}
\hline \multicolumn{1}{|c|}{ Nível da Alfabetização } & Porcentagem \\
\hline Alfabetizado & $51,59 \%$ \\
\hline Analfabeto & $48,15 \%$ \\
\hline Sem informação & $0,26 \%$ \\
\hline
\end{tabular}

Fonte: IBGE (1950, p. 6).

Entre os 51,59\% dos jovens alfabetizados, a relação racial é a seguinte:

Tabela 10 - Proporção racial de alfabetizados na população masculina em idade militar (entre 20 e 29 anos)

\begin{tabular}{|c|c|}
\hline Cor & Proporção \\
\hline Brancos & $76,52 \%$ \\
\hline Pardos & $15,42 \%$ \\
\hline Negros & $8,06 \%$ \\
\hline
\end{tabular}

Fonte: IBGE (1950, p. 6).

Assim, se o contingente da FEB fosse escolhido apenas entre os alfabetizados, ou seja, projetando-se a alfabetização sobre a base racial do Serviço Militar, o resultado proporcional seria o seguinte: brancos $73,92 \%$, pardos $21,19 \%$, negros 04,89\%. No entanto, esses números não podem ser considerados como um valor absoluto. Deve-se lembrar que, apesar das restrições aos analfabetos, mesmo uma proporção pequena (6.05\%) pertenceu à FEB, de acordo com a amostragem do DP/FEB. ${ }^{18}$ Dos 70 analfabetos encontrados no universo amostral de 1.156 expedicionários, 66 tinham informações raciais: 34 brancos, 25 pardos e 7 negros. Proporcionalmente, do número total de expedicionários, declararamse analfabetos 4,56\% dos expedicionários brancos, 7,91\% dos expedicionários pardos e $11,47 \%$ dos expedicionários negros. 
Tabela 11 - Proporção racial de analfabetos na FEB

\begin{tabular}{|c|c|c|c|}
\hline \multicolumn{2}{|c}{ Praças (total) } & Analfabetos & $\begin{array}{c}\text { \% de analfabetos em } \\
\text { relação ao grupo racial }\end{array}$ \\
\hline Brancos & 746 & 34 & $4,56 \%$ \\
\hline Pardos & 316 & 25 & $7,91 \%$ \\
\hline Negros & 61 & 7 & $11,4 \%$ \\
\hline $\begin{array}{c}\text { S/ informações } \\
\text { raciais }\end{array}$ & 33 & 4 & $12,12 \%$ \\
\hline TOTAL & 1156 & 70 & $6,05 \%$ \\
\hline
\end{tabular}

Fonte: DP/FEB.

Portanto, mesmo reduzindo radicalmente o número de analfabetos enviados para a Campanha da Itália, a FEB também expressou, na sua composição final, os problemas estruturais da sociedade que representava. Os brancos eram a maioria, mas contavam proporcionalmente com menos analfabetos do que os pardos e os negros.

Em conclusão, o requisito, mesmo formalizado, de um nível mínimo de instrução, seria um filtro capaz de excluir uma proporção maior de pardos e negros do que de brancos. A dedução mais lógica seria que todos esses filtros juntos selecionassem um grupo de elite menos pardo e preto, e mais branco do que a população brasileira.

\section{Perfil racial de praças}

É aí que se encontra o paradoxo: quando comparados os melhores dados disponíveis sobre a proporção racial da FEB (originados da DP/FEB) com dados do Censo Demográfico de 1940, os resultados contradizem os filtros. De acordo com a amostragem DP/FEB, a proporção racial das tropas expedicionárias é apenas ligeiramente diferente da população adulta masculina brasileira em 1940, obtida no Censo Demográfico:

Tabela 12 - Comparação entre as composições raciais da

Força Expedicionária Brasileira e as da população brasileira em 1940

\begin{tabular}{|c|c|c|}
\multicolumn{3}{c}{$\begin{array}{c}\text { População brasileira masculina } \\
\text { (Censo de 1940) }\end{array}$} \\
\hline Brancos & $63,7 \%$ & $64,5 \%$ \\
\hline
\end{tabular}




\begin{tabular}{|c|c|c|}
\hline Pardos & $21,0 \%$ & $27,3 \%$ \\
\hline Negros & $14,6 \%$ & $5,3 \%$ \\
\hline Amarelos & $00,6 \%$ & $0 \%$ \\
\hline S/ informação & - & $2,9 \%$ \\
\hline
\end{tabular}

Fonte: IBGE (1950); DP/FEB.

Portanto, apesar da aplicação de todos os critérios que levariam, involuntariamente, a FEB a apresentar uma proporção racial diferente da base da população brasileira, a composição final da divisão do Exército que embarcou e lutou na Campanha da Itália foi semelhante à da população do país, quanto à raça, em idade militar.

Para explicar este paradoxo, devemos voltar às práticas habituais das classes médias e altas do país, principalmente as brancas, para escapar dos sacrifícios do Serviço Militar, já mencionadas, para o caso do Serviço Militar em tempos de paz, pelo coronel Lobo da Silva. De fato, se em tempo de paz já ocorria evasão, quando houve a certeza de que os jovens selecionados seriam embarcados para enfrentar todos os riscos, as classes médias e altas fizeram tudo para conseguir evitar o alistamento nas unidades de combate. Usando abertamente as práticas de favor e clientelismo, os "melhores e mais brilhantes" foram mais bem sucedidos em livrar-se de pertencer à Força Expedicionária. Dispensas, adiamentos, transferências para unidades não-combatentes, isenções do Serviço Militar, todo tipo de ação foi usada para ficar longe do serviço ativo do Teatro de Operações. ${ }^{19}$ Até para as tarefas de defesa dentro do país havia resistência, como reclamou o ministro da Guerra Eurico Dutra em 1943, ao se referir a “... patrícios ... [que] reclamam futilidades e pretextos vários para se furtarem à simples ida para o nosso não muito longínquo Nordeste” (DUTRA..., 1943, p. 7-8). E Dutra acrescenta, sem esconder seu desalento:

Teríamos, aí, infelizmente, que reprochar severamente a massa culta da população, cujos filhos - mais capazes e competentes são o elemento requintado com que se nutrem os exércitos deste século ultra-civilizado e tão impregnado de ciência e de mecânica. Impossível hoje fazer a guerra ou conduzí-la com eficiência se não contarmos na base da estrutura militar com o espírito cultivado e o corpo sadio e forte da juventude nacional. [...] Para isso é preciso 
certa predisposição de espírito, profunda compreensão dos fatos, inteligência e caráter, que se não encontrará provavelmente na massa analfabeta, inculta e desprotegida do povo. Esta, de instinto, sabe contudo enxergar os bons exemplos que, neste particular lhe devem dar os ricos e abastados, como também vê e entende todos os que lhe inculquem de ruim ou de máu. Ora, se são sem número os péssimos exemplos dados por quem deveria, precisamente, servir-lhe de modelo, como, pois, obter bom êxito em empreendimento de tamanha gravidade - como soe ser a mobilização militar - se em todos os lados procuram-na fraudar? (DUTRA..., 1943, p. 7-8)

As vagas foram preenchidas principalmente por jovens de baixa renda e das classes trabalhadoras. Conforme mencionado anteriormente, os jovens que apresentaram resultados menos satisfatórios do que a coorte previamente selecionada tiveram que substituir as centenas de recrutados que foram dispensados, transferidos ou que tiveram seus engajamentos adiados. Mesmo alguns analfabetos pertenceram à Força Expedicionária e foram enviados para a guerra. Sem querer, a FEB obteve a proporcionalidade racial do país.

Assim, o exército que embarcou para a Itália foi uma amostra do "caldeirão de raças brasileiro", com a vantagem de ser a única tropa que realmente poderia apresentar uma integração racial. Como resultado, desenvolveu-se uma imagem que foi enviada à Campanha da Itália, uma espécie de amostra imperfeita, mas não menos verdadeira, da sociedade brasileira, em características educacionais e físicas. Em algumas características, essa amostra foi melhor do que a média brasileira como, por exemplo, a alfabetização dos expedicionários, a robustez física e as origens urbanas (MAXIMIANO, 2010, p. 56-63). Mas a imagem da FEB como exemplo do povo brasileiro ainda permanece, principalmente em características raciais.

Portanto, todos esses dados e argumentos levam à conclusão de que o tão celebrado "caldeirão de raças", a tal amostra da população brasileira em proporção e relações raciais, foi mais acidental do que o que era pretendido pelas autoridades militares. De fato, se os critérios de seleção dos expedicionários fossem seguidos até o final da formação da FEB, o perfil da FEB deveria ter a proporção de mais soldados brancos, em comparação com pardos e negros, do que realmente tinha. 


\section{Perfil racial de sargentos e oficiais}

Com a proporção étnica semelhante à da população brasileira, pelo menos entre os praças, a FEB embarcou para a Campanha da Itália. Resta tentar traçar um perfil racial dos postos e graduações na FEB, com a documentação disponível. Basicamente, temos uma série amostral com dados sobre "cor", com retratos fotográficos dos expedicionários e relatos memorialísticos sobre o assunto. Os dados das fichas não deixam dúvidas. Dos 1.156 expedicionários da amostragem, 77 eram sargentos. Destes, 69 eram "brancos” e 8 classificados como "mestiços". Nenhum sargento negro foi registrado como tal.

Os relatos memorialísticos, contudo, oferecem indícios de que havia, sim, sargentos e até mesmo oficiais subalternos negros na FEB. O generalde Exército Sebastião José Ramos de Castro, que na FEB combateu como $2^{\circ}$ tenente, menciona um oficial negro de Cavalaria, o $1^{\circ}$ tenente Kardec Leme, que foi designado para chefiar o Serviço de Transporte do Depósito de Pessoal da FEB. Segundo Ramos de Castro, aquele oficial “realizou um trabalho notável, inclusive se empenhando fisicamente, porque ele era um negro muito forte e removia obstáculos para preparar tudo da melhor maneira”. Além da cor da pele, Kardec Leme chamou a atenção do então subordinado por outro motivo: era abertamente comunista, "que não hesitava em fazer proselitismo junto aos seus oficiais e sargentos, em favor do comunismo" (CASTRO, 2001, p. 62). Sargentos negros dando ordem a praças brancos chamaram a atenção dos membros da já mencionada $92^{\text {a }}$ Divisão de Infantaria dos Estados Unidos. Um capitão americano questionou o sargento João Ferreira de Albuquerque, da Artilharia da FEB, se era costume um sargento negro brasileiro dar ordens a soldados brancos, ao que o sargento brasileiro respondeu não ver aquilo como problema (ALBUQUERQUE, 2001, p. 152). Espanto semelhante, por parte de soldados negros da Divisão Americana, em ver sargentos negros e pardos dando ordens a praças brancos, foi registrado pelo tenente brasileiro Hélio Amorim Gonçalves (2001, p. 318).

Os registros não são apenas de brasileiros, mas também de combatentes e correspondentes de guerra dos Estados Unidos, o que pode ser verificado nos artigos da imprensa ativista afro-americana durante a guerra (OLIVEIRA, 2017; ROSENHECK, 2015). Essa imagem idealizada de democracia e igualdade racial, inclusive nas oportunidades para oficiais negros, não resistiu, porém, a uma viagem ao Brasil por um correspondente do Pittsburgh Courier, o mais importante jornal da imprensa afro-americana, após o fim da guerra. No afã de 
verificar in loco a democracia racial brasileira, o jornalista ficou desapontado. Visitando várias unidades do exército no país, verificou que o discurso de ausência de racismo não combinava com a realidade que testemunhou. Uma das coisas que mais chamou sua atenção foi a desproporção entre brancos e negros no oficialato, em relação à população como um todo (DESPITE..., 1948, p. 7). Em suma: embora a amostragem das fichas dos praças mostre que sargentos negros e mestiços eram raros nas tropas, os registros memorialísticos de brasileiros e americanos apontam para sua presença, posto que em número muito aquém de sua proporcionalidade, em relação à população do país.

O mesmo ocorre com oficiais negros. Além de Kardec Leme, não foi encontrado outro registro de oficial negro na FEB, se bem que o caráter ainda incompleto da documentação febiana ofereça o benefício da dúvida. Um caso exemplar das dificuldades para a ascensão ao oficialato é o do futuro marechal João Baptista de Mattos. Neto de ex-escravos, Mattos conseguiu driblar todos os obstáculos interpostos à sua cor. Segundo depoimento de sua filha, Mattos, tenente-coronel à época da organização da FEB, desejou fazer parte do corpo de oficiais da divisão expedicionária. Seu pleito foi negado pelo ministro da Guerra, assim como ocorreu com dois outros oficiais não-brancos, Alencar Lima e Joaquim Vicente Rondon, que não puderam acompanhar os outros oficiais para treinamento nos Estados Unidos (FRANCISCO, 2017, p. 157). Terminada a guerra, o general Anor Teixeira dos Santos solicitou à Dutra para levar o tenentecoronel Mattos para a Alemanha, e Dutra novamente recusou, sugerindo que o general deveria levar "um branco" (FRANCISCO, 2017, p. 162). Esses dissabores não lhe provocaram ressentimento contra o Exército ou contra a FEB. Anos depois, Mattos (1960). desenvolveu uma pesquisa que gerou a obra-base para os estudos sobre os monumentos da FEB no Brasil, "Expedicionários no Bronze"

Nesse ponto, apesar da documentação ainda rarefeita, é possível dizer que a FEB reproduzia não apenas a proporção étnica da população brasileira, mas também, à sua maneira, as relações raciais. Do recrutamento às ações na Campanha da Itália, não houve, oficialmente, discriminação por parte do Exército, tampouco há registros oficiais de vedação à ascensão ao oficialato, para negros e mestiços, pelo menos naqueles que entraram na Escola Militar, nas décadas de 1920 e $1930^{22}$. Todavia, é inegável que essa discriminação ocorria, não no ponto de chegada - sentar praça como aspirante a oficial - mas nos inúmeros obstáculos que a população negra e mestiça tinha de enfrentar nos pontos de partida e ao longo do percurso de suas vidas. A desigualdade nas oportunidades profissionais, no acesso à educação, aos serviços de saúde e 
saneamento básico, nos contatos influentes na vida social, material e política, todos esses condicionantes dos pontos de partida, tornavam a chance de igualdade uma quimera. Essa desigualdade se mostrou brutal no momento do recrutamento para a guerra, pois aos negros e mestiços não havia possibilidade de utilizar padrinhos poderosos, no meio militar e civil, para facilitar as dispensas ou as transferências para unidades não-combatentes. O padrão já detectado no Serviço Militar voltou com toda força na hora da verdade da formação de tropas para uma guerra real.

Com as unidades expedicionárias já formadas, essa desigualdade racial, esse "racismo cordial", aparecia na desproporção de oficiais e mesmo sargentos negros e mestiços, comparada à proporção demográfica de negros e pardos da população brasileira. Se, por um lado, a negação do racismo no Brasil apela para a enumeração de negros e mestiços que "venceram" a corrida de obstáculos pelas oportunidades e ascensão social (a existência de sargentos e oficiais subalternos na FEB o comprova), os dados para a esmagadora maioria de não-brancos apontam, de maneira constrangedora, o contrário. $\mathrm{O}$ fato de tal discriminação ser velada não a faz menos real, e até a torna mais cruel, pois a "culpa” pela não-ascensão se desloca ignominiosamente da estrutura racial e socialmente discriminatória para as suas vítimas.

\section{Conclusões}

Sobre o perfil étnico da FEB, este estudo chegou às seguintes conclusões:

- A proporção de brancos é semelhante à do Censo Demográfico de 1940 (63.5\% do Censo, $64,5 \%$ da FEB);

- A soma de não-brancos (ou seja, mestiços e negros) da FEB é também semelhante a do Censo/1940: 36,2\% não-brancos no Censo, 32,6\% na FEB;

- No entanto, se o conjunto de não-brancos é parecido com aquele do Censo/1940, a distribuição entre negros e mestiços é significativamente diferente, nos levantamentos realizados por Ribeiro (2013), Piovezan (2017) e Rodrigues e Traldi (2017), em relação ao Censo de 1940;

- A explicação mais provável para esse fenômeno é o conjunto de práticas de "branqueamento", perceptível nas diferenças entre os retratos $3 \times 4$ dos expedicionários e as atribuições de cor nas fichas do DP/FEB, bem como na redução da atribuição de mestiçagem entre os mortos, em favor da 
atribuição ao grupo "branco", mantendo-se a atribuição ao grupo "negro" em proporção semelhante àquele do levantamento de Ribeiro (2013);

- Por fim, a seleção da FEB, em nenhum momento, intentou fazer da Divisão Expedicionária um "caldeirão de raças" representativo da população brasileira. Pelo contrário, objetivava reunir um grupo com melhor estado físico e grau de instrução para o imenso desafio de combater as Forças do Eixo. Na verdade, essas autoridades pretendiam recrutar uma "elite", com critérios de saúde física e alfabetização que poderiam ser excludentes para uma parte da juventude não-branca. No entanto, devido às dificuldades de recrutamento seletivo e evasão de parte das classes média e alta, predominantemente brancas, foi enviado para a guerra uma tropa com origens raciais e culturais que pode ser considerada uma espécie de "amostra" da sociedade brasileira.

Esse era o grupo que representava o país, com todas as suas qualidades e defeitos, como bem descreveu Ruben Braga. Mas, a sociedade, que enviou esses jovens para a guerra, guardava desconfianças sobre a capacidade desse grupo de brancos, negros e pardos ter um bom desempenho em combate. Contra tais expectativas, o "caldeirão das raças" derrotou a "raça superior" alemã. No entanto, terminada a guerra, as práticas cotidianas do racismo estrutural e de sua negação, que alimentavam a mitologia da relação harmônica entre os grupos étnicos no Brasil, continuaram as mesmas por todo o país.

\section{Referências}

ALBUQUERQUE, João Ferreira de. Entrevista. In: MOTTA, Aricildes (ed.). História oral do exército na segunda guerra mundial. Rio de Janeiro: Biblioteca do Exército Editora, 2001.v. 3, p. 147-157.

ANDRADE, Antonio Carlos Judá de. Reservas étnicas do exército. Nação Armada, Rio de Janeiro, n. 8, jul. 1940.

BEATTIE, Peter. The tribute of blood. army, honor, race and nation in Brazil, 18641945. Durham: Duke University Press, 2001.

BRAGA, Ruben. Crônicas de guerra na Itália. Rio de Janeiro: Record, 2005.

BRASIL. Ministério da Guerra. Relatório do Ministério da Guerra para o ano de 1939. Rio de Janeiro: Imprensa Militar, 1940. 
BRASIL. Ministério da Guerra. Relatório do Ministério da Guerra para o ano de 1940. Rio de Janeiro: Imprensa Militar, 1941.

BRASIL. Ministério da Guerra. Relatório do Ministério da Guerra, para o ano de 1941. Rio de Janeiro: Imprensa Militar, 1942.

BRASIL. Ministério da Guerra. Relatório do Ministério da Guerra, para o ano de 1943. Rio de Janeiro: Imprensa Militar, 1944.

BRASIL. Ministério da Guerra. Força Expedicionária Brasileira: Relatório Secreto - 1943-1945. [Rio de Janeiro: Imprensa Militar], 1945a. Arquivo Histórico do Exército.

BRASIL. Ministério da Guerra. Relatório do Ministério da Guerra para o ano de 1944. Rio de Janeiro: Imprensa Militar, 1945 b.

CASTRO, Sebastião José Ramos de. Depoimento. In: MOTTA, Aricildes (ed.). História oral do exército na segunda guerra mundial. Rio de Janeiro: Biblioteca do Exército Editora, 2001. v. 4, p. 55-65.

D’ÁVILA, Jerry. Diploma of whiteness. race and social policy in Brazil, 1917-1945. Durham: Duke University Press: Kindle Edition, 2003.

DUTRA ao Presidente Getúlio Vargas. Rio de Janeiro: Arquivo Histórico do Exército: Arquivo Góes Monteiro, 1943. Caixeta 11, Pasta 2, Subpasta 2, documento “d”.

FALCÃO, Ana Taísa da Silva. A Revista Medicina Militar: práticas eugênicas a “serviço da nação”, 1910-1923. 2012. Dissertação (Mestrado em História) Universidade Estadual do Rio de Janeiro, Rio de Janeiro, 2012.

FALA Sobre a abertura do voluntariado no exército o ministro Gaspar Dutra. Folha da Manhã, São Paulo, 1 jul. 1943.

DP/FEB. ( Depósito de Pessoal da FEB). Fichas de Reservistas. Arquivo Histórico do Exército. Rio de Janeiro, Arquivos FEB.

FERREIRA JUNIOR, Alcemar. Uma visceral rebeldia: clientelismo e isenções no recrutamento da Força Expedicionária Brasileira (1943-1944). In: SANTOS, Cláudia R. Andrade dos et al. Estudos. Curitiba: [Universidade Severino Sombra], 2007. v. 2. Série Grupo de Pesquisa LEPH/Programa de Mestrado em História Social. 
FRANCISCO, Alessa Passos. "Um preto de alma branca": escritas de si, redes de sociabilidade e mobilidade social na trajetória do Marechal João Baptista de Mattos nas primeiras décadas do século XX. 2017. Dissertação (Mestrado em História) - Universidade Federal Fluminense, Niterói, 2017.

GOMES, Ana C. V.; SILVA, André L. S.; VAZ, Alexandre F. O Gabinete biométrico da Escola de Educação Física do Exército: medir e classificar para produzir corpos ideais, 1930-1940. História, Ciências, Saúde - Manguinhos, Rio de Janeiro, v. 20, n. 4, out./dez. 2013.

GONÇALVES, Carlos Paiva. Seleção médica do pessoal da FEB, história, funcionamento e dados estatísticos. Rio de Janeiro: Biblioteca do Exército, 1951.

GONÇALVES, Helio Amorim. Entrevista. In: MOTTA, Aricildes (ed.). História oral do exército na segunda guerra mundial. Rio de Janeiro: Biblioteca do Exército Editora, 2001. v. 4, p. 299-320.

GUIMARÃES, Antonio Sérgio Alfredo. Raça, cor, cor da pele, etnia. Cadernos de Campo, São Paulo, v. 20, n. 20, p. 265-271, 2011.

HARGROVE, Hondon B. Buffalo soldiers in Italy: black americans in World War II. Jefferson: McFarland \& Company, 1985. Kindle Edition.

IBGE - INSTITUTO BRASILEIRO DE GEOGRAFIA E ESTATÍSTICA. Censo demográfico - 1940. Rio de Janeiro: IBGE, 1950.

MAGALHÃES, J. B. O que todos devem saber sobre mobilização (importância, evolução, aspectos sociais). Revista de Intendência, [Rio de Janeiro], ano 18, n. 16, jul./ago. 1944.

MATTOS, João Baptista de. Os monumentos nacionais: a força expedicionária no bronze. Revista Militar Brasileira, Rio de Janeiro, n. 1/2, jan./jun. 1960.

MAXIMIANO, Cesar Campiani. Barbudos, sujos e fatigados. soldados brasileiros na segunda guerra mundial. São Paulo: Grua, 2010.

MELO, Humberto de. Sugestão para utilização da Lei do Serviço Militar como instrumento acelerador da cultura do povo brasileiro. Revisa Militar Brasileira, Rio de Janeiro, ano 34, v. 43, n. 1/2, jan./jul. 1946.

MORAES, João Batista Mascarenhas de. A FEB pelo seu comandante. São Paulo: Instituto Progresso Editorial, 1947. 
OLIVEIRA, Anielly Tedesco. "V de vitória: A Força Expedicionária Brasileira e a Luta pelos Direitos Civis dos Negros Americanos (1944-1948)". In: Encontro de História Militar, 2., 2017, Porto Alegre. Anais [...]. Porto Alegre: Museu Militar do Comando Militar do Sul, 2017.

OLIVEIRA, Dennison; MAXIMIANO, Cesar Campiani. Raça e forças armadas: o caso da campanha da Itália (1944/45). Estudos de História, Franca, v. 8, n. 1, p. 157-184, 2001.

PAULA CIDADE, Francisco de. "Introdução”. In: SEIDLER, Carl. Dez anos no Brasil. Brasília: Senado Federal, 2003. p.13-26..

PIERO, Dante de. Educação física e o serviço militar. Revista de Medicina Militar, Brasília, ano 33, n. 2, abr.jun. 1944.

DESPITE Brazil's assurances, color bias continues to grow. Pittsburgh Courier, Pittsburgh, 4 set. 1948.

PIOVEZAN, Adriane. Morrer na guerra: a sociedade diante da morte em combate. Curitiba: CRV, 2017.

PIZA, Edith; ROSEMBERG, Fulvia. Cor nos censos brasileiros. Revista USP, São Paulo, n. 40, dez/1998-fevereiro/1999. p.122-137.

RIBEIRO, Frederico Soares. O exército de Caxias e o exército da FEB: história das relações entre os estabelecidos e os outsiders no Exército Brasileiro, 1942-1945. 2017. Dissertação (Mestrado em História) - Universidade Federal Rural do Rio de Janeiro, Rio de Janeiro, 2017.

RIBEIRO, Patrícia da Silva. Em luto e luta: construindo a memória da FEB. 2013. Tese (Doutorado em História) - Centro de Pesquisa e Documentação de História Contemporânea do Brasil - CPDOC, Fundação Getúlio Vargas, Rio de Janeiro, 2013.

RODRIGUES, Fernando da Silva. Indesejáveis, instituição, pensamento político e formação profissional dos oficiais do exército brasileiro (1905-1946). Jundiaí: Paco Editorial, 2010.

RODRIGUES, Matheus Moreto Guisso; TRALDI, Victor Hugo Bento da Costa. A questão da cor na força expedicionária brasileira: uma análise comparativa entre fichas de reservistas e o Censo Demográfico de 1940. In: CONGRESSO INTERNACIONAL DE HISTÓRIA, 8., 2017, Maringá. Anais [...]. Maringá: [s. n.], 
2017.

ROSENHECK, Uri. Fighting for home abroad: rememberance and oblivion of world war II in Brazil. Atlanta: Emory University, 2011.

ROSENHECK, Uri. Olive Drab in black and white: the Brazilian Expeditionary Force, the US Army and Racial National Identity. Esboços, Florianópolis, v. 22, n. 34, p. 142-160, 2015.

SCHWARCZ, Lilia Moritz. Censo e contrassenso: nomes e cores ou quem é quem no Brasil. In: Nem preto nem branco: cor e raça na sociabilidade brasileira. São Paulo: Claro Enigma, 2012.p. 97-120

SILVA, Arthur Lobo da. A anthropologia no exército brasileiro. Rio de Janeiro: Separata dos Archivos do Museu Nacional, 1928. v. 30.

SILVA, Arthur Lobo da. O serviço militar e a juventude brasileira. A Nação Armada, Rio de Janeiro, n. 16, mar. 1941.

SILVA, Arthur Lobo da. Ligeiras notas sobre as últimas estatísticas sanitárias do exército brasileiro. A Nação Armada, Rio de Janeiro, ano 1, n. 11, out. 1940.

SILVEIRA, Joaquim Xavier. A FEB por um soldado. Rio de Janeiro: Nova Fronteira, 1989.

SKIDMORE, Thomas.. Preto no branco: raça e nacionalidade no pensamento brasileiro, 1870-1930. São Paulo: Companhia das Letras, 2012.

STEPAN, Nancy. A hora da eugenia: raça, gênero e nação na América Latina. Rio de Janeiro, Fiocruz, 2005.

\section{Notas}

${ }^{1}$ Pesquisa financiada pelo Conselho Nacional de Pesquisa Científica (CNPq), Projeto "Serviço Militar e recrutamento para a Segunda Guerra Mundial: uma abordagem comparativa entre as experiências brasileiras e estadunidenses" (PQ-CNPq).

${ }^{2}$ Departamento de História, Universidade Estadual de Londrina.

${ }^{3}$ Embora reconheça que "raça" não existe como categoria biológica/sociológica, usarei esse conceito, ao invés de "etnia" ou "cor", uma vez que: 1) a documentação arquivística e bibliográfica o referem dessa maneira; 2) a noção de raça, embora imperfeita, “... tem vantagens estratégicas visíveis sobre aquela de etnia: remete imediatamente a uma história de opressão, desumanização e opróbio a que estiveram sujeitos os povos conquistados (GUIMARÃES, 2011, p. 266)”. Além do mais, “... a noção [de raça] é recuperada pela sociologia contemporânea como conceito nominalista - isto é, para 
expressar algo que não existindo, de fato, no mundo físico, tem realidade social efetiva (GUIMARÃES, 2011, p. 266)”.

4"Mestiços" ou “pardos" são denominações para pessoas de etnias miscigenadas, desenvolvidas historicamente. Assim como foi feito em relação ao conceito de "raça", ao longo do texto adotarei a expressão "pardo", usada na década de 1940 pelos agentes históricos estudados neste artigo, e pelo Censo Demográfico Brasileiro de 1940.

${ }^{5} \mathrm{O}$ papel desenvolvido por essa imagem positiva de relações raciais harmônicas nas memórias da FEB também foi discutido em Rosenheck (2011, p. 101, 282).

${ }^{6} \mathrm{~A} 92^{\mathrm{a}}$ divisão de infantaria dos Estados Unidos existe desde 1917, tendo combatido nas duas guerras mundiais. O nome "buffalo soldiers" é uma homenagem aos regimentos exclusivamente negros que combateram nas guerras contra indígenas, na década de 1860. Seja pelo contraste, na neve, da tropa de homens negros se abrigando do frio com peles de búfalo, seja pela bravura e ferocidade com que lutaram, os nativos americanos que os combatiam assim os chamavam, pois lembravam-lhes o modo resistente e tenaz como os búfalos lutavam (HARGROVE, 1985, pos 69-79/3926).

${ }^{7}$ Também conhecido como Centro de Recompletamento de Pessoal da FEB (CRP/FEB). A documentação está no Arquivo Histórico do Exército, Rio de Janeiro. DP/FEB - Fichas de Reservistas.

${ }^{8}$ Há ainda um terceiro estudo, também acadêmico (Mestrado em História), que utilizou as fichas de reservistas, feito por Frederico Soares Ribeiro (2017). A amostragem pesquisada por F. S. Ribeiro (1.162 fichas) foi ligeiramente diferente daquela de Patrícia Ribeiro (1.166) e de Rodrigues e Traldi (2017), (1.156), devido à inclusão, por F. S. Ribeiro, de fichas individuais de uma unidade pertencente à FEB no Brasil, mas que havia sido extinta antes do embarque para a Itália (Batalhão de Trabalhadores), assim como o descarte de fichas que apresentavam dúvidas sobre o militar ter embarcado com a FEB para a guerra (RIBEIRO, 2017, p. 45-46). Seus resultados são muito semelhantes àqueles de Rodrigues e Traldi: $66,17 \%$ brancos, $26,85 \%$ pardos, $5,16 \%$ negros e $1,82 \%$ sem informação. (RIBEIRO, 2017, p. 53). Para as finalidades deste artigo, as amostragens escolhidas foram as de Patrícia Ribeiro (2013) e a de Rodrigues e Traldi (2017), embora a pesquisa de F.S. Ribeiro vai oferecer, mais adiante, alguns elementos importantes.

${ }^{9} \mathrm{~A}$ FEB foi composta por uma Divisão de Infantaria Expedicionária (D.I.E.), que foi a tropa em ação de combate (15.069 homens) e pelos órgãos não-divisionários (10.265), totalizando 25.334 expedicionários. Os três regimentos de infantaria (9.762 homens), que concentraram $81.30 \%$ dos mortos da FEB, representaram $64,78 \%$ da D.I.E. e $38,53 \%$ de toda a FEB (SILVEIRA, 1989).

${ }^{10} \mathrm{O}$ Quarto Escalão de Embarque embarcou do Rio de Janeiro em 23 de novembro de 1944 e chegou ao porto de Nápoles em 7 de dezembro de 1944, conduzindo o $1^{\circ}$ Escalão de Depósito de Pessoal da FEB, com 4.691 homens, inclusive 285 oficiais. O Quinto Escalão de Embarque saiu do Rio de Janeiro em 8 de fevereiro de 1945 e chegou a Nápoles em 22 de fevereiro de 1945. Seu efetivo era composto por 5.082 homens, inclusive 247 oficiais. Ao todo, portanto, os dois escalões somaram 9.773 homens, sendo 9.241 praças e suboficiais e 532 oficiais (MORAES, 1947, p. 36).

${ }^{1}$ Cordeiro de Farias, Discurso, CPDOC/FGV, CFA 44.09.20tv, pa.1-22, (apud BEATTIE, 2001, p. 384). 
${ }^{12}$ Brasil $(1940,1941,1942)$.

${ }^{13}$ Brasil (1944, p.79-80).

${ }^{14}$ Brasil (1944, p.79-80).

${ }^{15}$ Mantive a grafia original. Reclamações sobre a tendência à "fuga” do Serviço Militar pelas classes mais privilegiadas também podem ser encontradas nos Relatórios Anuais do Ministério da Guerra, às vésperas do envolvimento brasileiro na Segunda Guerra Mundial. Brasil (1940, p. 13); Brasil (1942, p. 132-133).

${ }^{16}$ Essa entrevista e as regras de instrução mínima de quatro anos e idade entre 21 e 26 anos para o recrutamento de voluntários da FEB estão em: (FALA...,1943, p. 2). Agradeço a Cesar Maximiano por chamar-me a atenção para este documento.

${ }^{17}$ "As medidas para complemento dos efetivos, em face dos aspectos verdadeiramente alarmantes da Seleção Física, foram drásticas, extendendo-se para todas as Regiões Militares com resultados compensadores, principalmente pelos elementos oruindos das $3^{a}$ e $5^{a}$ R.M., que enviaram sucessivos contingentes selecionados criteriosamente. O mesmo não se deu com as $6^{a}$, $7^{a}$ e $10^{a}$ R.M., cujos contingentes apresentaram fortes índices de incapacidade, ao serem reinspecionados pela Junta da Policlínica Militar do Rio.” Brasil (1945a, p. 18). Mantive a grafia original.

${ }^{18}$ Esses dados se referem apenas a soldados. Cabos e sargentos eram todos alfabetizados, de acordo com os dados do DP/FEB.

${ }^{19}$ Críticas sobre as práticas de fuga às obrigações militares, especialmente concentrada na "juventude estudantil" são frequentes: Brasil (1940, 1944, 1945b, 1945a). Cf. também Magalhães (1944, p. 716-717); Um excelente levantamento e análise dessas "fugas” ao recrutamento para a FEB estão em Ferreira Junior (2007).

${ }^{20}$ Mantida a grafia original.

${ }^{21} \mathrm{Na}$ amostragem de Frederico S. Ribeiro, os resultados para os sargentos são ainda mais excludentes: 86 sargentos no total, 78 brancos, 8 pardos e nenhum negro (RIBEIRO, 2017, p. 57).

${ }^{22}$ Não se pode dizer o mesmo para ingressantes na Escola Militar entre 1937 e 1945, conforme demonstrou inequivocamente Fernando da Silva Rodrigues (2010), mas esse ingresso não repercutiu na formação da FEB. 